\title{
The Phytochemical and Thin Layer Chromatography Profile of Ethnomedcinal Plant Helicia Nilagirica (Bedd)
}

\section{Zoremsiami J and Jagetia GC* \\ Department of Zoology, Mizoram University, India}

*Corresponding author: Ganesh Chandra Jagetia, Department of Zoology, Mizoram University, Tanhril, Aizawl, Mizoram, India, 796 004, Tel: +919436352849; Email: gc.jagetia@gmail.com

\section{Research Article \\ Volume 2 Issue 2}

Received Date: February 17, 2018

Published Date: March 06, 2018

\section{Abstract}

The plants have provided valuable medicines in the form of secondary metabolites synthesized by them for various purposes. The present study deals with the phytochemical profiling of Helicia nilagrica using various phytochemical procedures and thin layer chromatography. The mature non-infected stem bark of Helicia nilagirica was collected, dried, powdered and subjected to sequential extraction with increasing polarity using petroleum ether, chloroform, ethanol and distilled water. The different extracts were cooled and evaporated to dryness with rotary evaporator. The phytochemical analyses were carried out on chloroform, ethanol and aqueous extracts. The chloroform extract revealed the presence of flavonoids, tannins, terpenoids, cardiac glycosides, whereas alkaloids, saponins and carbohydrates were completely absent. Similarly, the ethanol extract contained flavonoids, tannins, phenols and cardiac glycosides. The aqueous extract showed the presence of saponins, tannins, cardiac glycosides and carbohydrates. The TLC profile also showed the presence of different phytochemicals in the different extracts as indicated by different Rf values using various solvent systems.

Keywords: Helicia nilagirica; Phytochemical; Flavonoid; Thin layer chromatography

\section{Introduction}

Medicinal plants have been used as the main traditional herbal medicinal system amongst rural dwellers worldwide since antiquity and they are still in use for healthcare. The earliest written evidence of use of plants as medicine has been found around 5000 years before on a Sumerian clay slab from Nagpur which comprised of 12 recipes for drug preparation consisting over 125 plants including poppy, henbane and mandrake. The Rig Veda, the ancient knowledge book of Hindus dating between 3500 B.C. to 1800 B.C. mentions several plant-based drugs for human healthcare and is the earliest systematic record in this regard. In $2500 \mathrm{BC}$ the Chinese emperor has written a book for 365 drugs some of which have been used even today include Rhei rhisoma, camphor, Theae folium, Podophyllum, the great yellow gentian, ginseng, jimson weed, cinnamon bark, and ephedra [1,2]. Over the years plants have been used as the main source of medicine especially in the developing countries and more than $80 \%$ of the world's population relies on traditional medicine for their primary healthcare needs [3].

Phytochemicals are natural bioactive chemical compounds produced by various plants to protect themselves from environmental hazards such as pollution, 
stress, drought, UV exposure and pathogenic attack [4]. These compounds are known as secondary plant metabolites and include organic substances like alkaloids, carotenoids, glycosides, terpenoids, steroids, tannins, flavonoids, saponins, vitamins, mucilages, minerals, organic acids etc. [5-8]. These secondary metabolites are of great health benefits to humans. Some of the beneficial roles of phytochemicals include low toxicity, low cost, easy availability with an extensive range of therapeutic activities such as antioxidant, antimicrobial, hypoglycemic, antidiabetic, antimalarial, anticholinergic, antileprotic and antineoplastic. These phytochemicals also help in the modulation of detoxification of enzymes, stimulation of the immune system, decrease in platelet aggregation and modulation of hormone metabolism $[9,10]$. Even with a remarkable progress made in synthetic drugs in modern medicine, therapies using medicinal plants still make a major contribution to the pharmaceutical industry because of their safety, easy availability, and cost effectiveness. They also have synergistic effect with other biologically active ingredients due to the presence of beneficial minerals $[11,12]$.

Helicia nilagirica Bedd. (Family:Proteaceae) is locally known as Pasaltakaza, is a medium-sized tree, which grows up to a height of 12 meters. It is widely distributed in Sri Lanka, southern India, Burma (Myanmar), Indochina, Japan, Taiwan, and Thailand. It is also found scattered in lowland to montane rain forests, up to an altitude of 500 3,350 meters. Some species are found in habitats along the streams whereas other species are found on hilltops or ridges [13]. It has been used as folk medicine since time immemorial in Mizoram, India by the Mizo people. The decoction prepared by boiling the leaves or bark is used to treat various stomach ailments including peptic ulcers, indigestion, mouth ulcer, urinary tract infection and gynecological disorders. The stem bark juice is applied to reduce muscular swelling and treat cuts and wounds. The stem bark is also used in scabies and other skin diseases [14]. H. nilagirica has been shown to possess antiinflammatory and antioxidant properties recently $[15,16]$. H. nilagirica has been found to be cytotoxic in cultured HeLa cells indicating its anticancer potential in treating neoplastic disorders [17]. The fruits of H. nilagirica have been used as a medicine to cure cough and cold in Sikkim [18]. Helicia nilagirica has been used in traditional medicine by the people of Mizoram and other states for healthcare and the information has been collected by meeting the elders who practice ethnomedicine. There are only very few reports about phytochemical analysis of Helicia nilagirica and these studies were done on methanol extract and not all parameters were evaluated $[14,19]$. The ethnomedicinal use and scanty information on the phytochemical analysis of Helicia nilagirica stimulated us to investigate its phytochemical composition.

\section{Materials and Methods}

\section{Chemicals and reagents}

Potassium iodide, bismuth nitrate, sulphuric acid, ferric chloride, hydrochloric acid, aluminium chloride, ammonium hydroxide, glacial acetic acid, chloroform, ethanol, methanol, n-butanol, ethyl acetate, sodium chloride, sulphuric acid, olive oil, and Whatman filter paper were procured from Sd fine Chemical Ltd., Mumbai, India. The TLC plates were commercially procured from Merck India, Mumbai.

\section{Collection and extraction}

The mature and non-infected stem bark of Helicia nilagirica Bedd. (Family: Proteaceae) locally known as Pasaltakaza was collected from Sialsuk, Aizawl District of Mizoram, India during the dry season. Identity of Helicia nilagirica Bedd was authenticated by the Botanical Survey of India, Shillong. The cleaned and non-infected bark was spread into stainless steel trays and allowed to dry in the shade at room temperature in dark in clean and hygienic conditions to avoid entry of insects, animals, fungus, and extraneous terrestrial materials. The exhaust and free air circulation was allowed. The dried bark was powdered in a grinder at room temperature. A sample of $100 \mathrm{~g}$ of stem bark powder was extracted sequentially in chloroform, ethanol and water in a Soxhlet apparatus. Each extract was concentrated to dryness under reduced pressure and stored at $-80^{\circ} \mathrm{C}$ until further use.

\section{Phytochemical Screening}

The different extracts of Helicia nilagirica were analyzed for the presence of various phytochemicals using standard procedures as described below.

\section{Alkaloids}

The presence of alkaloids was determined by mixing $0.1 \mathrm{~g}$ of the extract with $0.5 \mathrm{ml}$ of Mayer's reagent and Dragendorff's reagent. The formation of a creamy (Mayer's reagent) or reddish-brown precipitate (Dragendorff's reagent) indicated the presence of alkaloids $[20,21]$.

\section{Tannins}

About $0.5 \mathrm{~g}$ of dried powdered samples was boiled in 20 $\mathrm{ml}$ of water in a test tube and filtered. A few drops of $0.1 \%$ ferric chloride was added to the filtrate. The formation of 
brownish green or a blue-black colour indicated the presence of tannins [20,21].

\section{Phlobatannins}

The aqueous extract of Helicia nilagirica was boiled with $1 \%$ aqueous hydrochloric acid and deposition of a red precipitate indicated the presence of phlobatannins $[20,21]$.

\section{Saponins}

About $2 \mathrm{~g}$ of the powdered sample was boiled with 20 $\mathrm{ml}$ of distilled water in a water bath for 10 minutes and filtered while hot and cooled before conducting the following tests:

Frothing: $3 \mathrm{ml}$ of filtrate was diluted up to $10 \mathrm{ml}$ with distilled water and shaken vigorously for 2 minutes. The formation of a fairly stable froth indicated the presence of saponins in the filtrate.

Emulsification: 3 drops of olive oil was added to the solution obtained by diluting $3 \mathrm{ml}$ filtrate to $10 \mathrm{ml}$ distilled water and shaken vigorously for a few minutes. The formation of a fairly stable emulsion indicated the presence of saponins $[20,21]$.

\section{Flavonoids}

Three different methods were used to test the presence of flavonoids in all the extracts [20,21,22]. $5 \mathrm{ml}$ of dilute ammonia solution was added to a portion of the aqueous filtrate of each sample followed by the addition of concentrated $\mathrm{H}_{2} \mathrm{SO}_{4}$. Appearance of a yellow colour (disappeared on standing) in each extract indicated the presence of flavonoids.

a) A few drops of $1 \%$ aluminum solution were added to a portion of each filtrate. A yellow colour indicated the presence of flavonoids.

b) A portion of the sample was heated with $10 \mathrm{ml}$ of ethyl acetate over a steam bath for $3 \mathrm{~min}$. The mixture was filtered and $4 \mathrm{ml}$ of the filtrate was shaken with $1 \mathrm{ml}$ of dilute ammonia solution. A yellow colour indicated the presence of flavonoids.

\section{Terpenoids}

The presence of terpenoids was detected as follows:

Salkowski test: Five $\mathrm{ml}$ of each extract was mixed with 2 $\mathrm{ml}$ of chloroform, with a careful overlaying of $3 \mathrm{ml}$ concentrated sulphuric acid. The formation of a reddishbrown precipitate at the interface indicated the presence of terpenoids [23].

\section{Cardiac glycosides (Keller-Killani test)}

The cardiac glycosides were determined by adding $5 \mathrm{ml}$ of each extract in $2 \mathrm{ml}$ of glacial acetic acid containing one drop of ferric chloride solution that was underlayed with $1 \mathrm{ml}$ of concentrated sulphuric acid. The appearance of brown ring at the interface indicated the presence of deoxysugar, which is a characteristic of cardenolides $[20,21]$.

\section{Carbohydrates}

The presence of carbohydrates in each extract of Helicia nilagirica was detected by the Benedict's test, where the filtrates of the extracts were treated with Benedict's reagent and heated gently. The appearance of orange red precipitate indicated the presence of reducing sugars.

\section{Quantitative Determination of The Phytochemicals}

The quantitative determination of saponins and flavonois was also carried out as described below.

\section{Determination of Saponins}

$20 \mathrm{~g}$ of Helicia nilagirica powder was weighed in a conical flask and $100 \mathrm{ml}$ of $20 \%$ aqueous ethanol was added. The sample was heated over a hot water bath for 4 $\mathrm{h}$ with continuous stirring at $55{ }^{\circ} \mathrm{C}$. The mixture was filtered and the residue was re-extracted with another 200 $\mathrm{ml}$ of $20 \%$ ethanol. The combined extracts were reduced to $40 \mathrm{ml}$ in a water bath at $90^{\circ} \mathrm{C}$. The concentrate was transferred into a $250 \mathrm{ml}$ separating funnel with the addition of $20 \mathrm{ml}$ of diethyl ether and shaken vigorously. The aqueous layer was recovered while the ether layer was discarded. The purification process was repeated and $60 \mathrm{ml}$ of n-butanol was added. The combined n-butanol extracts were washed twice with $10 \mathrm{ml}$ of $5 \%$ aqueous sodium chloride. The remaining solution was heated in a water bath. After evaporation, the samples were dried in the oven to a constant weight and saponin contents were calculated as percentage [24].

\section{Determination of Flavonoids}

Ten $g$ of the bark powder of Helicia nilagirica was extracted repeatedly with $100 \mathrm{ml}$ of $80 \%$ aqueous methanol at room temperature. The whole solution was filtered through Whatman filter paper No. $42(125 \mathrm{~mm})$. The filtrate was later transferred into a crucible and evaporated to dryness over a water bath and weighed [25]. 


\section{Determination of Moisture Content}

Determination of the amount of volatile matter (i.e., water drying off from the drug) in the Helicia nilagirica is a measure of loss after drying of substances appearing to contain water as the only volatile constituent. The powdered bark of Helicia nilagirica was accurately weighed, placed (without preliminary drying) in a tared evaporating dish, dried at $105^{\circ} \mathrm{C}$ for 5 hours, and weighed again. The percentage moisture content was calculated with reference to the initial weight. The moisture content was calculated using the following formula:-

Moisture content $=\mathrm{Pw}-\mathrm{Fw} / \mathrm{W} \times 100$

Where $\mathrm{Pw}=$ Preweighed sample

$\mathrm{Fw}=$ Final weight of the dried sample

$\mathrm{W}=$ Total weight of the sample

\section{Ash values}

The ash values including total and acid insoluble ash were determined to estimate the total amount of the inorganic salts present in the drug. The ash contents remained after ignition of plant material was determined by two different methods to measure total and acid insoluble ash contents.

\section{Total Ash Contents}

The method measures the total amount of material remaining after ignition including both 'physiological ash', derived from the plant tissue itself, and 'non-physiological ash' which is the residue of the extraneous matter (e.g. sand and soil) adhering to the plant surface.

Procedure: Two grams of ground air-dried material of Helicia nilagirica was accurately weighed in a previously ignited and tared crucible. The material was spread as an even layer and ignited by gradually increasing the temperature up to $500-600^{\circ} \mathrm{C}$ until it became white, indicating the absence of carbon. The crucible was cooled and weighed. The percentage of total ash content was calculated according to the following formula. Total ash content $=\mathrm{Pw}-\mathrm{Fw} / \mathrm{W} \times 100$

Where $\mathrm{Pw}=$ Preweighed crucible

$\mathrm{Fw}=$ Final weight of the crucible containing ash

$\mathrm{W}=$ Total weight of powdered plant material

\section{Extractive Values}

These are used to determine the amount of the matter which is soluble in the solvents used including alcohol and water. The percentage of alcohol and water-soluble extractives were calculated and used as standards.

\section{Determination of Alcohol-Soluble Extractive}

Procedure: Five grams of air dried coarsely powdered material was macerated in $100 \mathrm{ml}$ of alcohol in a closed conical flask for twenty-four hours, with frequent shaking during first six hours and allowed to stand for next eighteen hours thereafter it was filtered rapidly with caution to avoid loss of solvent. The $25 \mathrm{ml}$ of the filtrate was evaporated to dryness at $105^{\circ} \mathrm{C}$ in a tared flatbottomed shallow dish and weighed. The percentage of alcohol-soluble extractive was calculated with reference to the air-dried material.

\section{Determination of Water-Soluble Extractive}

Procedure: Five grams of coarsely powdered air-dried material was macerated in $100 \mathrm{ml}$ of chloroform-water $(0.1 \%)$ in a closed flask for $24 \mathrm{~h}$, shaken frequently until six hours and allowed to stand for another eighteen hours. Thereafter it was filtered rapidly, with precautions to avoid loss of solvent by evaporation. The $25 \mathrm{ml}$ of the filtrate was evaporated to dryness at $105^{\circ} \mathrm{C}$ in a tared flatbottomed shallow dish and weighed. The percentage of water soluble extractive was calculated with reference to the air-dried material. All the tests were done in triplicate.

\section{TLC Analysis}

TLC is a simple and rapid technique that is able to determine the number of components present in solution and helps in finding a suitable solvent for separating the components by column chromatography as well as for monitoring reactions' progress. The chloroform ethanol and aqueous extracts of $H$. nilagirica were spotted on to a number of TLC plates (Merck India, Mumbai) in $1 \mathrm{~mm}$ diameter above the bottom of the plates and placed into different mobile phases. The extracts were allowed to move on the adsorbent (Stationary) phase according to the solvent system used. Several combinations of solvents of increasing polarity were evaluated as mobile phase for TLC run to determine the number of compounds present in different extracts of Helicia nilagirica. The different solvent systems were used as mobile phase for TLC, which consisted of chloroform: methanol (9:1, 8:2), pure chloroform, chloroform: ethyl acetate (1:1) and methanol: hydrochloric acid (9:1) solvent combinations. The resultant spots were observed under visible and ultraviolet light at $254 \mathrm{~nm}$ and $365 \mathrm{~nm}$. The measure of the distance of a compound travelled is considered as the 
retention factor $\left(\mathrm{F}_{\mathrm{ry}}\right)$ value which was calculated using the following formula: -

$F_{r y}=$ Distance travelled by solute/Distance travelled by solvent

\section{Results}

The results of phytochemical analyses and TLC profiling of Helicia nilagirica are presented in Table 1-6 and Figures 1-3.

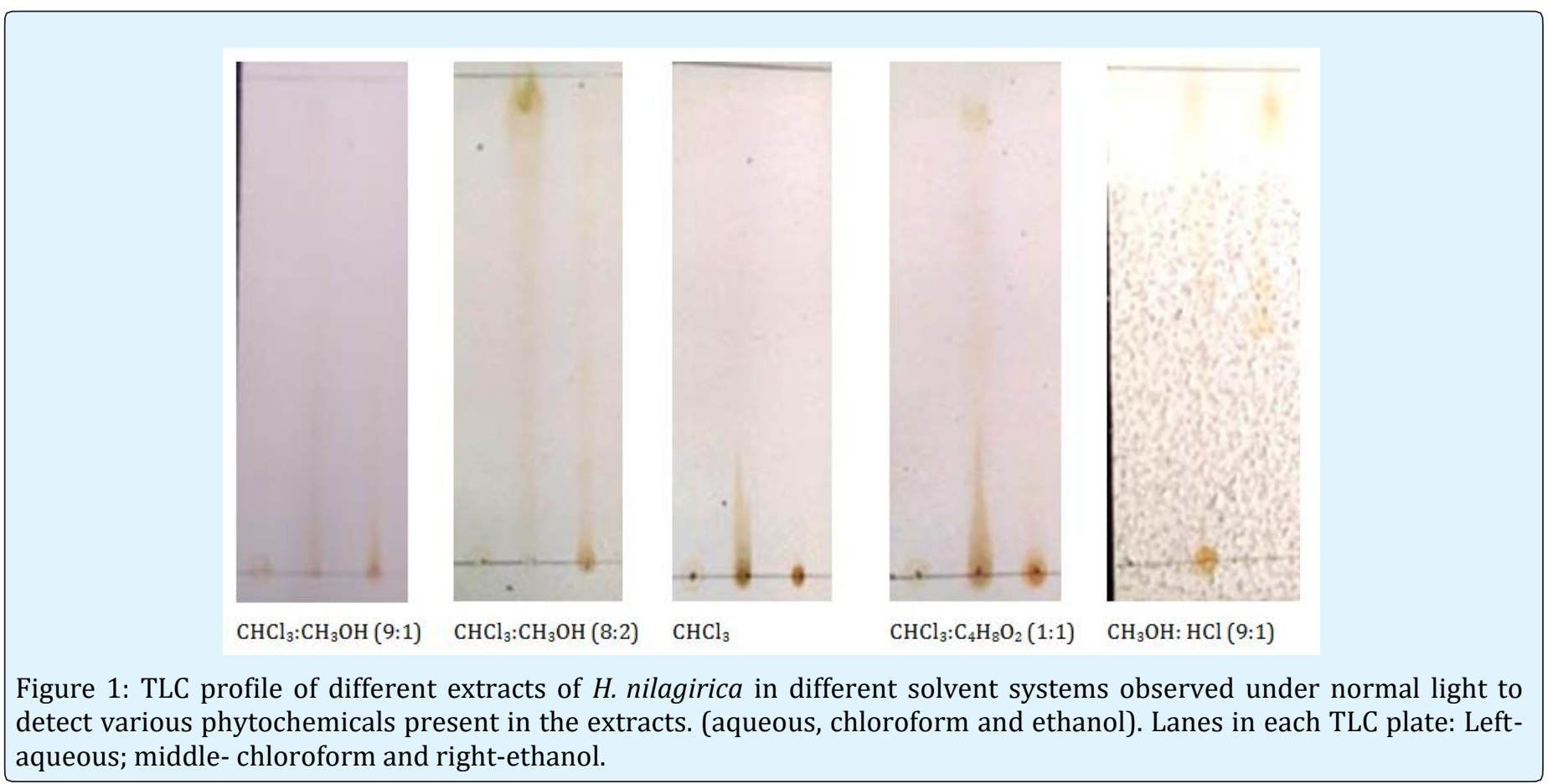

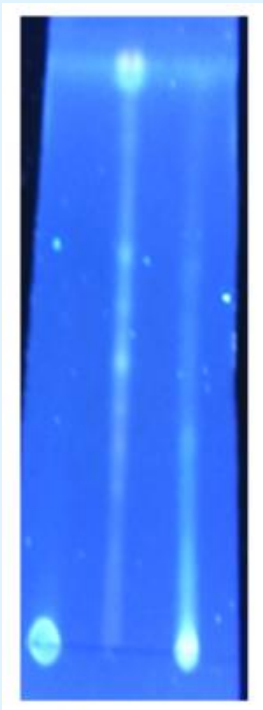

$\mathrm{CHCl}_{3}: \mathrm{CH}_{3} \mathrm{OH}(9: 1)$

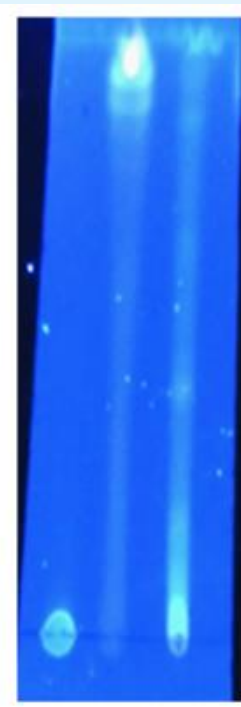

$\mathrm{CHCl}_{3}: \mathrm{CH}_{3} \mathrm{OH}(8: 2)$

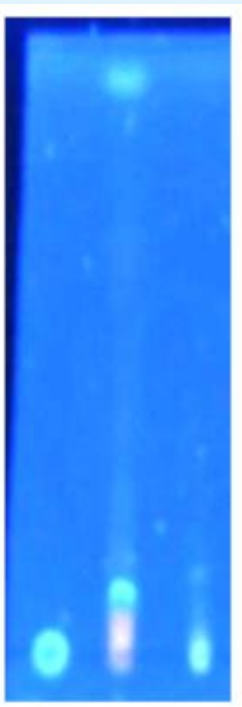

$\mathrm{CHCl}_{3}$

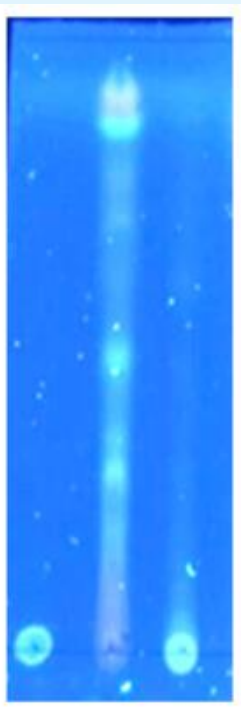

$\mathrm{CHCl}_{3}: \mathrm{C}_{4} \mathrm{H}_{8} \mathrm{O}_{2}$

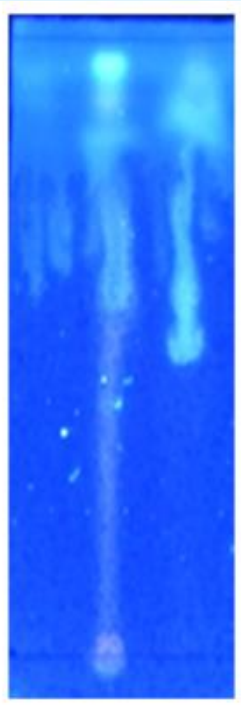

$\mathrm{CH}_{3} \mathrm{OH}: \mathrm{HCl}(9: 1)$

Figure 2: TLC profile of $H$. nilagirica with different solvent systems observed under UV $365 \mathrm{~nm}$ to detect phytochemicals present in the different extracts. Lanes in each TLC plate: Left- aqueous; middle- chloroform and right-ethanol. 


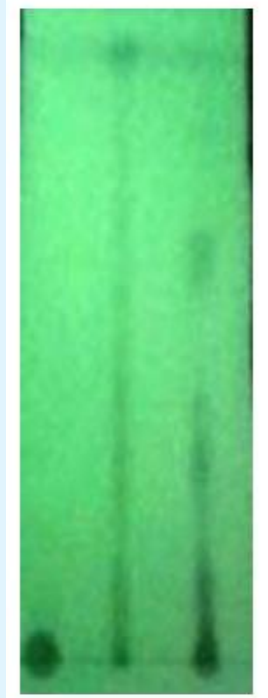

$\mathrm{CHCl}_{3}: \mathrm{CH}_{3} \mathrm{OH}(9: 1)$

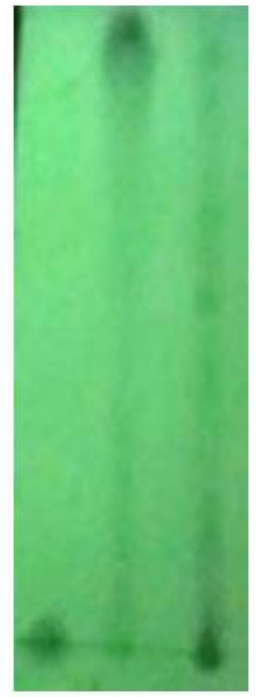

$\mathrm{CHCl}_{3}: \mathrm{CH}_{3} \mathrm{OH}(8: 2)$

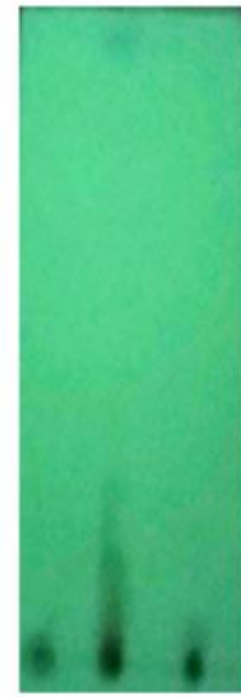

$\mathrm{CHCl}_{3}$

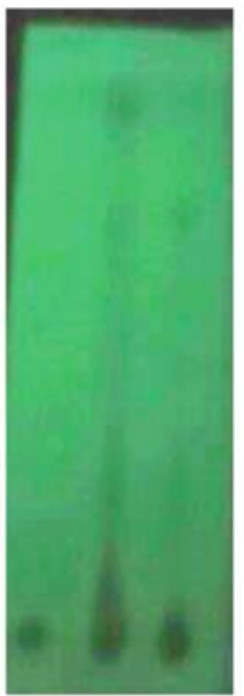

$\mathrm{CHCl}_{3}: \mathrm{C}_{4} \mathrm{H}_{8} \mathrm{O}_{2}(1: 1)$

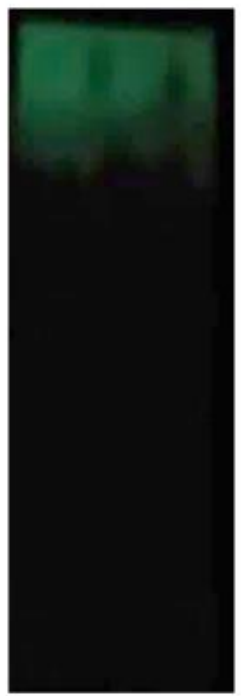

$\mathrm{CH}_{3} \mathrm{OH}: \mathrm{HCl}(9: 1)$

Figure 3: TLC profile of $H$. nilagirica on different solvent systems observed under UV $254 \mathrm{~nm}$ to detect phytochemicals present in the extracts. Lanes in each TLC plate: Left- aqueous; middle- chloroform and right-ethanol.

\section{Phytochemical analysis}

The phytochemical screenings of chloroform extract of Helicia nilagirica showed the presence of flavonoids, tannins, terpenoids, diterpenes, cardiac glycosides, whereas the alkaloids, saponins and carbohydrates were conspicuous by their absence (Table 1). The phytochemical analysis of ethanol stem bark extract of Helicia nilagirica revealed that it contained only flavonoids, phenols, tannins and cardiac glycosides. The other phytochemicals like, alkaloids, saponins, terpenoids and carbohydrates. flavonoids, phenol and terpenoids were not detected (Table 1). In aqueous extract tannins, saponins, cardiac glycosides and carbohydrates were detected, whereas all other phytochemicals could not be detected and the phlobatannins were absent in all extracts (Table 1).

\begin{tabular}{|c|c|c|c|}
\hline Tests & Chloroform extract & Ethanol extract & Water extract \\
\hline Alkaloids & - & - & - \\
\hline Phenols & + & + & - \\
\hline Flavonoids & + & + & + \\
\hline Tannins & + & - & - \\
\hline Terpenoids & - & - & - \\
\hline Phlobatannins & + & - & - \\
\hline Diterpenes & - & + & + \\
\hline Saponins & + & - & + \\
\hline Cardiac glycosides & - & + \\
\hline Carbohydrates & + & + \\
\hline
\end{tabular}

Table 1: Results of the Phytochemical analysis of Helicia nilagirica.

\section{Quantitative determination of phytochemicals}

The quantitative determination of the chemical constituents showed that Helicia nilagirica contained
9.26\% and $0.26 \%$ flavonoids and saponins, respectively (Table 2). 


\begin{tabular}{|c|c|c|c|c|c|c|}
\hline Plant & \multicolumn{3}{|c|}{ Flavonoid } & \multicolumn{3}{c|}{ Saponin } \\
\hline \multirow{2}{*}{ Helicia nilagirica } & Quantity & Output & $\%$ & Quantity & Output & $\%$ \\
\cline { 2 - 7 } & $10 \mathrm{~g}$ & $0.9256 \mathrm{~g}$ & 9.256 & $20 \mathrm{~g}$ & $0.051 \mathrm{~g}$ & 0.26 \\
\hline
\end{tabular}

Table 2: Quantitative determination of the chemical constituent of Helicia nilagirica.

\section{Determination of moisture content}

The drying of $500 \mathrm{~g}$ of Helicia nilagirica bark yielded $296 \mathrm{~g}$ of dried bark, and this reduction in weight was due to $40.6 \%$ loss in its water contents. The analysis of dried bark of Helicia nilagirica showed presence of $25.63 \%$ moisture (Table 3).

\begin{tabular}{|c|c|c|c|}
\hline Weight before drying (kg) & Weight after drying (kg) & Loss after drying (\%) & Moisture content (\%) \\
\hline 0.5 & 0.296 & 40.6 & 25.63 \\
\hline
\end{tabular}

Table 3: Weight loss on drying fresh bark of Helicia nilagirica.

\section{Determination of total ash content}

The ash content of the crude bark powder was found to be $3.24 \%$ (Table 4 ).

\begin{tabular}{|c|c|c|}
\hline $\begin{array}{c}\text { Total ash } \\
\text { (\%) }\end{array}$ & $\begin{array}{c}\text { Ethanol- soluble } \\
\text { extractive (\%) }\end{array}$ & $\begin{array}{c}\text { Water- soluble } \\
\text { extractive (\%) }\end{array}$ \\
\hline 3.24 & 3.4 & 8 \\
\hline
\end{tabular}

Table 4: Physicochemical parameters of dried bark powder of Helicia nilagirica.

\section{Determination of extractive values}

The Helicia nilagirica bark was found to contain 3.4\% ethanol-soluble and $8 \%$ water-soluble extractives (Table 4).

\begin{tabular}{|c|c|c|c|c|c|c|c|}
\hline Extract & Solvent & Day light & $\mathbf{R}_{\mathrm{f}}$ value & UV 254 nm & $R_{f}$ value & UV $365 \mathrm{~nm}$ & $\mathbf{R}_{\mathrm{f}}$ value \\
\hline Chloroform & \multirow{3}{*}{ 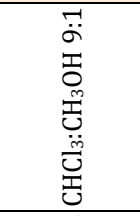 } & Streak & - & Two spots & $0.92,0.53$ & $\begin{array}{l}5 \text { spots ( } 1 \text { red, } 1 \text { blue, } \\
3 \text { yellowish) }\end{array}$ & $\begin{array}{c}0.92,0.86,0.57 \\
0.5 \& 0.42\end{array}$ \\
\hline Ethanol & & Streak & - & 3 spots & $\begin{array}{c}0.57,0.28 \& \\
0.09\end{array}$ & Not clear & 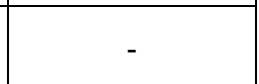 \\
\hline Aqueous & & Not visible & - & Not visible & - & Not visible & - \\
\hline Chloroform & \multirow{3}{*}{ 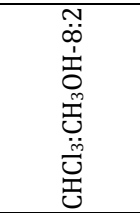 } & One spot & 0.94 & 1 spot & 0.94 & $\begin{array}{c}3 \text { spots (1 red, } 2 \\
\text { bluish) }\end{array}$ & $0.94,0.88 \& 0.84$ \\
\hline Ethanol & & Streak & - & 3 spots & $\begin{array}{c}0.90,0.82 \& \\
0.5\end{array}$ & 1 spot (bluish) & 0.38 \\
\hline Aqueous & & Not visible & - & Not visible & - & Not visible & - \\
\hline Chloroform & \multirow{3}{*}{ 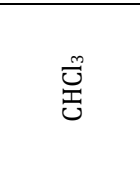 } & Not visible & - & 1 spot & 0.94 & $\begin{array}{c}3 \text { spots (1 bluish, } 2 \\
\text { red) }\end{array}$ & $\begin{array}{c}0.94,0.09 \& \\
0.05)\end{array}$ \\
\hline Ethanol & & Not visible & - & Not clear & - & 1 spot (bluish) & 0.11 \\
\hline Aqueous & & Not visible & - & Not visible & - & Not visible & - \\
\hline Chloroform & \multirow{3}{*}{ 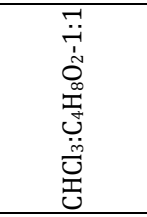 } & One spot & 0.9 & 3 spots & $\begin{array}{c}0.90,0.69 \& \\
0.48\end{array}$ & $\begin{array}{c}4 \text { spots (1 reddish, } 3 \\
\text { bluish) }\end{array}$ & $\begin{array}{c}0.90,0.86 \& \\
0.84\end{array}$ \\
\hline Ethanol & & Not visible & - & 3 spots & $\begin{array}{c}0.69,0.42 \& \\
0.23\end{array}$ & Not visible & - \\
\hline Aqueous & & Not visible & - & Not visible & - & Not visible & - \\
\hline
\end{tabular}

Extract yield: The extraction of Helicia nilagirica stem bark yielded $2 \%, 4 \%$ and $6 \%$ chloroform, ethanol and water extracts (Table 5).

\begin{tabular}{|c|c|c|c|}
\hline $\begin{array}{c}\text { Dried } \\
\text { powder }\end{array}$ & $\begin{array}{c}\text { Chloroform } \\
\text { extract (\%) }\end{array}$ & $\begin{array}{c}\text { Ethanol extract } \\
(\%)\end{array}$ & $\begin{array}{c}\text { Water } \\
\text { extract (\%) }\end{array}$ \\
\hline $100 \mathrm{~g}$ & 2 & 4 & 6 \\
\hline
\end{tabular}

Table 5: Yield of various extracts of Helicia nilagirica.

\section{TLC Analysis}

The evaluation of chloroform and ethanol extracts of Helicia nilagirica showed the presence of different components as indicated by a varying number of spots and colours on a TLC plates using UV visualization method (Table 6). 


\begin{tabular}{|c|c|c|c|c|c|c|c|}
\hline Chloroform & \multirow{3}{*}{ 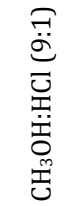 } & One spot & 0.86 & 1 spot & 0.84 & $\begin{array}{l}2 \text { spots ( } 1 \text { reddish, } 1 \\
\text { bluish) }\end{array}$ & $0.94 \& 0.79$ \\
\hline Ethanol & & Two spots & $\frac{0.82}{0.43}$ & 1 spot & 0.84 & Not clear & - \\
\hline Aqueous & & Not visible & - & Not visible & & Not visible & - \\
\hline
\end{tabular}

Table 6: TLC profile of the different extracts of Helicia nilagirica on pre-coated aluminium TLC plates.

\section{Discussion}

Plants synthesize several phytochemicals, which have played an important role in the development of new therapeutic agents. The preliminary qualitative phytochemical analysis of the bark of Helicia nilagirica revealed the presence of phenol, flavonoid, tannins, saponins, cardiac glycosides and carbohydrates. These phytochemicals synthesized by plants are essential for the growth, pathogen attack, pollination, defence and other activities of plants [26,27]. However, at the same time these phytochemicals are of great use for humans as a source of drugs and other healthcare agents [28-30].

Flavonoids consist of a large group of polyphenolic compounds having a benzo- $\gamma$-pyrone structure which are ubiquitously present in plants. Approximately, more than 10000 flavonoids have been identified $[31,32]$. They can be divided into a variety of classes such as flavones (e.g., apigenin, and luteolin), flavanols (e.g., quercetin, kaempferol, myricetin, and fisetin), flavanones (e.g., flavanone, hesperetin, and naringenin), and others [33,34]. They are the hydroxylated phenolic substances synthesized by plants in response to microbial infection [35]. Flavanols are the most abundant flavonoids in foods and they are generally responsible for colour, taste, prevention of fat oxidation, and protection of vitamins and enzymes [36]. Flavonoids have been consumed by humans since the advent of human life on earth. They have extensive biological properties that promote human health and help to reduce the risk of diseases and they are known to possess antioxidant, hepatoprotective, antibacterial, anti-inflammatory, anticancer and antiviral properties [3741]. The Helicia niglagirica have shown the presence of flavonoids like other plants. These results are in conformation with earlier studies, where the presence of flavonoids has been reported in the methanol extract of $H$. nilagirica [15]. The flavonoids have also been detected in $H$. nilagirica recently [19]. Earlier, flavonoids were detected in Croton caudatus and Oxylium indicum and several other plants from our laboratory $[28,29]$.

The presence of tannins in the Helicia nilagirica is in conformation with other studies where various plants have been reported to contain tannins [28,29]. Tannins are polyphenols which occur widely in vascular plants particularly associated with woody tissues. They are water soluble and have molecular weights ranging between 500 and 3000 Daltons. Based on the chemical structures, tannins are divided into two groups: hydrolysable, and condensed. The hydrolysable tannins consist of gallic acid esters, and ellagic acid glycosides [41]. They possess an amazing astringent property, which is mainly related to their drug applications. They are known to be antimicrobial, antifungal, anthelmintic, antiviral, antiulcer. They are known to hasten the healing of wounds and alleviate inflammation in mucous membranes [42-44]. They exert internal anti-diarrheal and antiseptic effects by waterproofing the outer layers of more exposed mucous membranes. Tannins are also haemostatic, and can serve as an antidote in poisoning cases [45]. In the process of healing wounds, burns and inflammations, tannins help by forming a protective layer (tannin-protein/tanninpolysaccharide complex), over injured epithelial tissues permitting the healing process below to occur naturally. Studies show that many tannins act as radical scavengers, intercepting active free radicals [41]. Various degenerative diseases such cancer, multiple sclerosis, atherosclerosis and aging process itself are associated with high concentrations of intercellular free radicals and tannins are useful in these conditions.

Terpenoids are synthesized from five carbon isoprene units mainly isopentenyl pyrophosphate and its isomerdimethylallyl pyrophosphate by the enzyme terpene synthases. They are classified according to whether they contain two $\left(\mathrm{C}_{10}\right)$, three $\left(\mathrm{C}_{15}\right)$, four $\left(\mathrm{C}_{20}\right)$, six $\left(\mathrm{C}_{30}\right)$ or eight $\left(\mathrm{C}_{40}\right)$ isoprene units. They range from the essential oil components, the volatile mono-and sesquiterpenes $\left(\mathrm{C}_{10}\right.$ and $\left.\mathrm{C}_{15}\right)$ through the less volatile diterpenes $\left(\mathrm{C}_{20}\right)$ to the involatile triterpenoids and sterols $\left(\mathrm{C}_{30}\right)$ and carotenoid pigments $\left(\mathrm{C}_{40}\right)$. Each of these various classes play a significant role in plant growth, metabolism or ecology [20]. Approximately 40,000 terpenes have been identified and the possible functions of majority of these molecules are not known [46]. Terpenoids have been found to be useful in the prevention and therapy of several diseases, including cancer. They possess antimicrobial, antifungal, antiparasitic, antiviral, anti-allergenic, antispasmodic, anti-malarial, antihyperglycemic, anti- 


\section{International Journal of Pharmacognosy and Chinese Medicine}

inflammatory and immunomodulatory properties [47-51]. Terpenoids can also be used as protective substances in storing agriculture products as they are known to have insecticidal properties as well [52].

Saponins are naturally occurring structurally and functionally diverse phytochemicals that are widely distributed among seventy families of plants. They are glycosides of both triterpenes and sterols [53]. Due to the presence of both the hydrophobic aglycone backbone and hydrophilic sugar molecules the saponins are highly amphipathic and possess foaming and emulsifying properties. They play an important role in plant ecology and they are also exploited for a wide range of commercial applications in the food, cosmetic and pharmaceutical sectors [54,55]. These molecules are potent membrane permeabilizing agents with immunostimulatory, hypocholesterolemic, anti-carcinogenic, antiinflammatory, anti-microbial, anti-protozoan, molluscicidal and have anti-oxidant properties [56,57]. Saponins also act as antitumor agents by inhibiting tumor cell growth and inducing apoptosis [42]. Terpenoids and saponins were detected in Helicia nilagirica like other plants. An earlier study has also reported the presence of saponins in Helicia nilagirica [19]. Likewise, several other plants have been found to synthesize terpenoids and saponins $[28,29]$.

Cardiac glycosides composed of two structural features: The sugar (glycoside) and the non-sugar (aglyconesteroid) moieties and they act on the contractile action of the cardiacmuscle. These compounds have long been used for the treatment of cardiac arrhythmias and congestive heart failure due to their capability to increase the contractile force [58]. Digitalis is the most commonly used cardiac glycoside, which directly inhibits the proliferation of androgen dependent and androgen independent prostate cancer cell lines by initiating apoptosis and increasing intracellular $\mathrm{Ca}^{2+}$. Cardiac glycosides have been reported to inhibit the four genes that are over expressed in prostate cancer cells including the inhibitors of apoptosis and transcription factors [59]. Cardiac glycosides have been reported to act as active anticancer agents $[60,61]$. They are also reported to have antiviral properties against human cytomegalovirus [62]. The Helicia nilagirica has been found to contain cardiac glycosides. Similarly, the glycosides have been detected in the methanol extract of stem bark of $H$. nilagirica [15]. The other plants have been reported to contain the cardiac glycosides $[28,29]$. The presence of these phytochemicals may have been responsible for its anticancer activity in our earlier study [17].

\section{Conclusions}

The phytochemical analyses have revealed the presence of different phytochemicals including, phenols, flavonoids, tannins, terpenoids, saponins, cardiac glycosides in the different extracts. However, alkaloids and phlobatannins were not present in this plant. The presence of various phytochemicals affirms its ethnomedicinal use in Mizoram.

\section{Acknowledgements}

The financial assistance provided by the Department of Biotechnology, and University Grants Commission Government of India, New Delhi to carry out this study to GCJ is thankfully acknowledged.

\section{Conflict of interest statement}

The authors do not have any Conflict of interest statement to declare.

\section{References}

1. Bottcher H (1965) Miracle drugs. Zagreb: Zora, pp: 23139.

2. Wiart C (2006) Ethnopharmacology of medicinal plants. New Jersey: Humana Press; pp: 1-50.

3. WHO (2013) traditional medicine strategy: 20142023.

4. Leonov A, Arlia-Ciommo A, Piano A, Svistkova V, Lutchman V, et al. (2015) Longevity extension by phytochemicals. Molecules 20(4): 6544-6572.

5. Bravo L (1998) Polyphenols: chemistry, dietary sources, metabolism, and nutritional significance. Nutr Rev 56(11): 317-333.

6. Brown L, Rimm EB, Seddon JM, Giovannucci EL, Chasan TL, et al. (1999) A prospective study of carotenoid intake and risk of cataract extraction in US men. Am J Clin Nutr 70(4): 517-524.

7. Gosslau A, Chen KY (2004) Neutraceuticals, apoptosis and disease prevention. Nutrition 20(1): 95-102.

8. Heber D (2004) Vegetables, fruits and phytoestrogens in the prevention of diseases. J Postgrad Med 50(2): 145-149.

9. Andre CM, Larondelle Y, Evers D (2010) Dietary antioxidants and oxidative stress from a human and 
plant perspective: a review. Curr Nutr Food Sci 6(1): 212.

10. Negi JS, Singh P, Rawat B (2011) Chemical constituents and biological importance of Swertia: a review. Curr Res Chem 3: 1-15.

11. Farnsworth NR, Soejarto DD (1991) Global importance of medicinal plants. In Akerele $\mathrm{O}$ et al. $\mathrm{H}$ (eds) Conservation of Medicinal Plants, Cambridge University Press, Cambridge, UK, pp: 25-51.

12. Jagetia GC (2017) Phytochemical composition and pleotropic pharmacological properties of Jamun, Syzygium cumini Skeels. J Explor Res Pharmacol 2(2): 54-66.

13. Khamyong S, Lykke AM, Seramethakun D, Barfod AS (2004) Species composition and vegetation structure of an upper montane forest at the summit of Mt. Doi Inthanon, Thailand. Nord J Bot 23(1): 83-97.

14. Sawmliana M (2003). The book of Mizoram Plants. $1^{\text {st }}$ (edn), Aizawl: Lois Bet.

15. Lalawmpuii $P$, Malsawmtluangi C, Zothanpuia, Kakoti BB (2014) Phytochemical screening and determination of antioxidant activity of Helicia nilagirica Bedd., an ethnomedicinal plant of Mizoram, India. Asian J Pharm Clin Res 7(5): 246-249.

16. Lalawmpuii $\mathrm{P}$, Malsawmtluangi C, Vanlalruata $\mathrm{R}$, Kakoti BB (2016) Evaluation of anti-inflammatory activity of Helicia nilagirica Bedd on cotton pelletinduced granuloma in rats. Int J Pharm Sci 8(7): 455456.

17. Zoremsiami J, Jagetia GC (2017) Evaluation of the cytotoxic effects of Helicia nilagirica Bedd in vitro. Int J Sci Res 6(9): 497-502.

18. Chauhan AS (2001) Ethnobotanical Studies in Sikkim Himalaya. Proceedings of national seminar on traditional knowledge based on herbal medicines and plant resources of north-east India. National Institute of Science Communication and Information Resources, CISR, New Delhi, 3: 200-204.

19. Buragohain R (2017) Tree foliages fed to dairy animals in Mizoram: Traditional medicinal uses, screening and quantification of phytochemicals. Int J Curr Microbiol Appl Sci 6(10): 61-71.
20. Harborne JB (1998). Phytochemical methods. A guide to modern techniques of plant analysis $3^{\text {rd }}$ (edn), London: Chapman and Hall.

21. Doughari JH (2012): Phytochemicals: extraction methods, basic structures and mode of action as potential chemotherapeutic agents, phytochemicals - A global perspective of their role in nutrition and health. Dr. Venkateshwara Rao (edn.), InTech, Rijeka, Croatia.

22. Trease GE, Evans WC (1989) Pharmacognosy. $11^{\text {th }}$ (edn), Brailliar Tiridel Can, McMillian publishers.

23. Sofowara A (1993). Medicinal plants and traditional medicine in Africa. Spectrum Books Ltd, Ibadan, Nigeria, pp: 289.

24. Brinda P, Sasikala B, Purushothaman K (1981). Pharmacognostic studies on Merugan kilzhangu. BMEBR 3: 84-96.

25. Boham BA, Kocipai-Abyazan R (1974) Flavonoids and condensed tannins from leaves of Hawaiian Vaccinium vaticulatum and V. calycinium. Pacific Sci 48(4): 458463.

26. Reymond P, Weber H, Damond M, Farmer EE (2000) Differential gene expression in response to mechanical wounding and insect feeding in Arabidopsis. Plant Cell 12: 707-719.

27. Hermsmeier D, Schittko U, Baldwin IT (2001) Molecular interactions between the specialist herbivore Manduca sexta (Lepidoptera, Sphingidae) and its natural host Nicotiana. I. Large-scale changes in the accumulation of growth- and defense-related plant mRNAs. Plant Physiol 125(2): 683-700.

28. Shantabi L, Jagetia GC, Vabeiryureilai M, Lalrinzuali $\mathrm{K}$ (2014) Phytochemical screening of certain medicinal plants of Mizoram, India and their folklore use. J Bio Biopros Dev 2(1): 136.

29. Lalrinzuali K, Vabeiryureilai M, Jagetia GC (2015) Ethnomedicinal use and phytochemical analysis of selected medicinal plants of Mizoram, India. Trends in Green Chemistry 1: 8.

30. Ferrer J, Austin M, Stewart C J, Noel J (2008) Structure and function of enzymes involved in the biosynthesis of phenylpropanoids. Plant Physiol Biochem 46(3): 356-370. 
31. Weston LA, Mathesius U (2013) Flavonoids: their structure, biosynthesis and role in the rhizosphere, including allelopathy. J Chem Ecol 39(2): 283-297.

32. Brodowska KM (2017) Natural flavonoids: classification, potential role, and application of flavonoid analogues. Eur J Biol Res 7(2): 108-123.

33. Middleton E J (1998) Effect of plant flavonoids on immune and inflammatory cell function. Adv Exp Med Biol 439: 175-182.

34. Dixon RA, Dey P M, Lamb C J (1983) Phytoalexins: enzymology and molecular biology. Adv Enzymol Relat Areas Mol Biol 55: 1-136.

35. Yao LH, Jiang YM, Shi J, Tomás-Barberán FA, Datta $\mathrm{N}$ et al. (2004) Flavonoids in food and their health benefits. Plant Foods f Hum Nutr 59 (3): 113-122.

36. Ferry DR, Smith A, Malkhandi J, Fyfe DW, deTakats PG, et al. (1996) Phase I clinical trial of the flavonoid quercetin: pharmacokinetics and evidence for in vivo tyrosine kinase inhibition. Clin Cancer Res 2(4): 659668.

37. Manthey JA (2000) Biological properties of flavonoids pertaining to inflammation. Microcirculation 7(1): 2934.

38. Li BQ, Fu T, Dongyan Y, Mikovits J A, Ruscetti FW, et al. (2000) Flavonoid baicalin inhibits HIV-1 infection at the level of viral entry. Biochem Biophys Res Commun 276(2): 534-538.

39. Kelly EH, Anthony RT, Dennis JB (2002) Flavonoid antioxidants: chemistry, metabolism and structureactivity relationships. J Nutr Biochem (10): 572-584.

40. Kumar S, Pandey AK (2013) Chemistry and biological activities of flavonoids: an overview. Sci. World J 2013.

41. Simões CMO, Schenkel EP, Gosmann G, Mello JCP, Mentz LA (2003) Farmacognosia da Planta ao Medicamento, $5^{\text {th }}$ (edn), Editora da UFRGS: Porto Alegre, Brasil, pp: 424.

42. Li K, Diao Y, Zhang H, Wang S, Zhang Z, et al. (2011) Tannin extracts from immature fruits of Terminalia chebula Fructus Retz. Promote cutaneous wound healing in rats. BMC Complement Altern Med 11: 86.

43. Theisen LL, Erdelmeier CA, Spoden GA, Boukhallouk F, Sausy A (2014) Tannins from Hamamelis virginiana Bark Extract: Characterization and improvement of the antiviral efficacy against influenza $A$ virus and human papillomavirus. PLoS One 9(1): e88062.

44. Williams AR, Fryganas C, Ramsay A, Mueller-Harvey I, Thamsborg SM (2014) Direct anthelmintic effects of condensed tannins from diverse plant sources against Ascaris suum. PLoS One 9(5): e97053.

45. Albuquerque UP, Monteiro JM, Araújo EL (2005) Taninos: uma abordagem da química à ecologia. Quim. Nova 28(5): 892-896.

46. Goto T, Takahashi N, Hirai S, Kawada T (2010) Various terpenoids derived from herbal and dietary plants function as PPAR modulators and regulate carbohydrate and lipid metabolism. PPAR Res 2010.

47. Mujoo K, Haridas V, Hoffmann JJ, Wächter GA, Hutter LK, et al. (2001) Triterpenoid saponins from Acacia victoriae (Bentham) decrease tumor cell proliferation and induce apoptosis. Cancer Res 61: 5486-5490.

48. Wagner KH, Elmadfa I (2003). Biological relevance of terpenoids: Overview focusing on mono-di and tetraterpenes. Ann Nutr Metab 47: 95-106.

49. Rabi T, Bishayee A (2009) Terpenoids and breast cancer chemoprevention. Breast Cancer Res Treat 115(2): 223-239.

50. Salminen A, Lehtonen M, Suuronen T, Kaarniranta K, Huuskonen J (2008) Terpenoids: natural inhibitors of $\mathrm{NF}-\kappa \mathrm{B}$ signaling with anti-inflammatory and anticancer potential. Cell Mol Life Sci 65(19): 29792999.

51. Grace MH, Esposito D, Dunlap KL, Lila MA (2013) Comparative analysis of phenolic content and profile, antioxidant capacity, and anti-inflammatory bioactivity in wild Alaskan and commercial vaccinium berries. J Agri Food Chem 62(18): 4007-4017.

52. Sultana N, Ata A (2008) Oleanolic acid and related derivatives as medicinally important compounds. J Enzyme Inhib Med Chem 23(6): 739-756.

53. Hostettmann K, Marston A (2005) Saponins. Cambridge University Press, Cambridge, UK.

54. Güçlü-Ustündağ O, Mazza G (2007) Saponins: properties, applications and processing. Crit Rev Food Sci Nutr 47(3): 231-258. 
55. San Martín R, Briones R (1999) Industrial uses and sustainable supply of Quillaja saponaria (Rosaceae) saponins. Econ Bot 53(3): 302-311.

56. Francis G, Kerem Z, Makkar HP, Becker K (2002). The biological action of saponins in animal systems: a review. Br J Nutr 88(6): 587-605.

57. Sparg SG, Light ME, Van Staden J (2004) Biological activities and distribution of plant saponins. J Ethnopharmacol 94(2-3): 219-43.

58. Liu J, Tian J, Haas M, Shapiro JI, Askari A, et al. (2000) Ouabain interaction with cardiac $\mathrm{Na}+\mathrm{K}+-\mathrm{ATPase}$ initiates signal cascades independent of changes in intracellular $\mathrm{Na}+$ and $\mathrm{Ca} 2+$ concentrations. J Biol Chem 275: 27838-27844.
59. Newman RA, Yang P, Pawlus AD, Block KI (2008) Cardiac glycosides as novel cancer therapeutic agents. Mol Intervent 8(1): 36-49.

60. Kepp 0, Menger L, Vacchelli E, Adjemian S, Martins I, et al. (2012) Anticancer activity of cardiac glycosides: At the frontier between cell-autonomous and immunological effects. Oncoimmunology 1(9): 16401642.

61. Calderón-Montaño JM, Burgos-Morón E, Orta ML, Maldonado-Navas D, García-Domínguez I, et al. (2014) Evaluating the cancer therapeutic potential of cardiac glycosides. BioMed Res Int 2014.

62. Kapoor A1, Cai H, Forman M, He R, Shamay M, et al. (2012) Human cytomegalovirus inhibition by cardiac glycosides: Evidence for involvement of the hERG gene. Antimicrob Agents Chemother 56(9): 48914899. 